Journal of Business \& Management (COES\&RJ-JBM)

ISSN (E): 2306-7179 ISSN (P): 2306-8043

Publisher: Centre of Excellence for Scientific \& Research Journalism, COES\&RJ LLC

Online Publication Date \& Issue: 1st January 2018, Vol.6, No.1, January 2018

https://doi.org/10.25255/jbm.2018.6.1.66.83

\title{
Transforming Online Negative Blogs in the Use of Credit Cards in Electronics Transactions into Constructive Action: Basis of Creating Business Spend Analyzer Model
}

\begin{abstract}
:
This exploratory qualitative research aimed at combining the negative perception of cardholders to negative blogs in using a credit card purchasing power in order to develop a new business model and spent analyzer, i.e., transforming online negative blogs in the use of credit cards in electronic transactions as basis for creating a business spend analyzer model. Specifically, it looked into the negative blogs posted by the credit card holders in terms of visa/master cards electronic business transactions, the analysis of negative blogs to produce a useful information for the visa and master cards holder, and the creation of business spend analyzer model. There were 1793 blogs considered and used in the study and 12 themes emerged namely; failure to transact payments, failure to reflect payments, failure to update, failure to give discounts, no reward points, excessive annual fees, failure to use, no cash out, too many calls, received threats, legal letters and experienced embarrassing situation. Based on the analysis of the online negative blogs, Semantia software had been used and revealed that the sentiment analysis is .024 and generally neutral, however its neutrality tends to be more into negative as the number of negative blogs is becoming more evident against the positive words. Modifying the model and removing the Acquirer entity can save the credit card holders in paying the hidden cost and can just be converted to savings. The used of spent analyzer is acceptable as it gradually allows the credit card holder to recover from the net of debt.

Keywords:

negative blogs, credit cards, electronic transactions, spend analyzer mode Citation:

Nagarit, Nenita B.; Bautista, Susana C.; Somido, Ferinand C.; Bermudo, Pedrito Jose V.; Yango, Antonio D.; Galicia, Leomar S.; (2018); Transforming Online Negative Blogs in the Use of Credit Cards in Electronics Transactions into Constructive Action: Basis of Creating Business Spend Analyzer Model; Journal of Business \& Management (COES\&RJ-JBM) Vol.6,No.1,pp.66-83, https://doi.org/10.25255/jbm.2018.6.1.66.83.
\end{abstract}

Nenita B. Nagarit, DBA

Susana C. Bautista, EdD

Ferdinand C. Somido, PhD

Pedrito Jose V. Bermudo, PhD

Antonio R. Yango, PhD

Leomar S. Galicia, PhD

This work is licensed under a Creative Commons Attribution 4.0 International License. 


\section{Introduction}

An electronic transaction is the sale or purchase of goods or services, whether between businesses, households, individuals, governments, and other public or private organizations, conducted over computer-mediated networks. In the past 25 years, credit card has become almost universally held product as shown by an increase in credit card ownership from $4 \%$ to $77 \%$ (Johnson, 2007). Credit card ownership and usage have substantially increased in recent decades (Wickramasinghe \& Gurugamage, 2009). Credit card ownership is so widespread among consumers in some of the rich and economically developed countries that penetration rates are approaching $100 \%$. Credit cards are similarly becoming increasingly available in many parts of developing countries (AbdulMuhmin \& Umar, 2007).

In Asia, the liberalization of the financial sectors has resulted in the rapid proliferation of credit card companies (Gan et al., 2008). In the Philippines, credit cards provided by the banking industry are an emerging source of household credit (Tan, 2009). The credit card outstanding loans in the country grew to Php 190.55 billion at the end of the year 2013, with an average annual increase of $7.89 \%$ from 2008 (Banko Sentral ng Pilipinas [BSP], 2014a). This trend reflects the growing popularity of the credit card as a preferred mode of payment for goods and services in lieu of cash, checks, and other forms of payment (Abdul-Muhmin \& Umar, 2007). Notably, there is a growing notion about its purchasing power in lieu with almost if not all companies allowed and accepted the use of credit cards. In the Philippines, the rate of consumer defaults almost triples the average in Asia (Estayo, 2008). For the last five years, the average non-performing loans or past due accounts amount to Php18.02 billion. Defaults of payment among cardholders could lead to higher credit expense due to compounding interests and penalties. Worsening the problem, the credit card interest rates in the country are currently among the highest in the world (Tan, 2009). On average, consumers end up paying $3.5 \%$ interest rate per month or $42 \%$ per annum on past due accounts while the average lending rate of commercial banks only ranges from 6.21\% per annum in the start of first-quarter of 2013 to $5.72 \%$ per annum at the end of the forth-quarter of 2013 (BSP, 2014a). The highinterest margin is imposed by banks on credit cards because credit risk is inherent in the industry; credit card transactions do not require collateral and high transaction costs can be incurred if banks go to court in the case of defaults (Cayanan \& Ledesma, 2005). Therefore, the credit card industry becomes problematic if credit cards are given to the consumers who do risky credit card activities. Despite the situation, there is still an immense marketing campaign among credit card issuers in the country. The increase in credit card usage among consumers is due to the developing nature of the financial system in the country (BSP, 2014b). There is a need to educate consumers in using a credit card by proposing a business model and spent analyzer.

This study aimed to transform online negative blogs in the use of credit cards in electronic transactions as basis for creating a business spend analyzer model. Specifically, it sought answers to the following questions: What are the negative blogs posted by the credit card holders in terms of visa/master cards electronic business transactions? How the negative blogs be analyzed and be able to produce a useful information for the visa and master cards holder?. How can a business Spend Analyzer model be created? 


\section{Methods}

In the study, a qualitative research was adopted due to its primarily exploratory research in nature. It is used to gain an understanding of underlying reasons, opinions, and motivations. It provides insights into the problem or helps to develop ideas or hypotheses for potential quantitative research (Wyse, 2011). Qualitative Research is also used to uncover trends in thought and opinions, and dive deeper into the problem. Qualitative data collection methods vary using unstructured or semi-structured techniques. Some common methods include focus groups (group discussions), individual interviews, and participation/observations. The sample size is typically small, and respondents are selected to fulfill a given quota (Rhodes, 2014).

To collect the blog, the researcher visited several blogging site related to credit cards to be analyzed. The data collected from the internet underwent using special software called Semantria. Likewise, the negative blogs that were collected were classified according to the issuing bank and subject to interpretation and analysis. The researcher asked several friends to navigate and look for blogs about the use of credit cards specifically dealing with the complaints of using the credits cards in purchasing and other related matters. Some of her friends emailed to the sites, some copied and sent to the researcher by text and via email. There were almost 1000 blogs gathered in the study. The data or blogs were also cleansed and considered only those English sentences although the blogs have been also translated into English.

Theme Analysis: Sentiment and Theme Extraction was utilized. To correlate the results of the perception of using the credit cards and blogs, document analysis and theme extraction using a special software called Semantria was used to analyze the digital transcripts of the of the online blogs. Semantria software extracts themes using the digital transcript of the blogs taken from the online blogs to determine and follow trends that appear over a period of time. Themes are noun phrases extracted from text and are the primary means of identifying the main ideas within the digital transcript. In addition, Semantria assigns a sentiment score to each extracted theme to understand the tone behind the themes.

After the digital transcript was sent to Semantria, the engine identified the basic parts of speech called POS tags. Figure 3.2 demonstrates how two simultaneous steps occur:

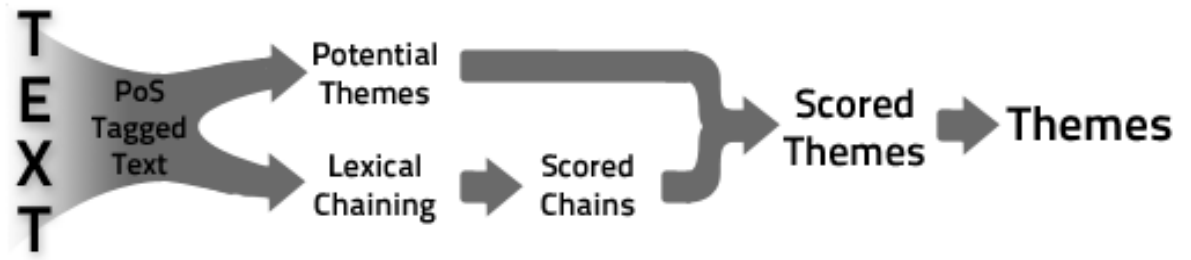

Theme Extraction (Semantria, 2014)

i. Potential themes are extracted from POS tags and kept for scoring. A process called Lexical Chaining occurs, which involves linking sentences through nouns that are synonyms or otherwise related to each other. In this way, Semantria is able to establish a conceptual chain in the content. 
ii. Once the Lexical Chaining and Potential Theme Extraction steps are finished, each theme is scored based on Semantria's algorithms. Potential themes that belong to the highest Lexical Chain are assigned the highest score. The algorithm also takes context and noun-phrase placement into account when scoring themes. If there are fewer than four chains in the given text, the algorithm reverts to scoring purely based on count.

\section{Results}

1. The negative blogs posted by the credit card holders in terms of visa/master cards electronic business transactions.

Table 4.1 shows the 12 themes that dominantly observed from the 1793 blogs collected during the online collation of negative blogs. Out of the 1793 blogs, 929 is noted for Visa Card or 51.2 percent while the remaining 883 or 48.8 percent is allocated for Master Card. With the 12 themes extracted "failure to update" or checking the credit cards for an update online is a common negative blogs from the blogs frequency analysis. It can be noted also that "failure to transact payments" is the second highest theme of negative blogs with 169 male and female accounts. The total male for visa cars is 469 while for master card is 460 , an almost equal number of bloggers for both credit cards. The female of visa is composed of 450 while 414 for master cards. It can be said that majority of the credit cards holder based on the gathered blogs are male. This statistics is valid because majority of the workforce are male almost $57 \%$ while woman is almost $47 \%$ (Houston Chronicle, 2013).

Table 4.1: Dominant Theme of Negative Blogs

\begin{tabular}{|l|c|c|c|c|}
\hline \multirow{2}{*}{ Negative Blogs } & \multicolumn{2}{c|}{ Visa Card } & \multicolumn{2}{c|}{ Master Card } \\
\cline { 2 - 5 } & Male & Female & Male & Female \\
\hline Failure to Transact Payments & 50 & 50 & 36 & 33 \\
\hline Failure to Reflect Payments & 38 & 27 & 41 & 28 \\
\hline Failure to Update & 42 & 41 & 43 & 47 \\
\hline Failure to Give Discounts & 37 & 34 & 48 & 38 \\
\hline No rewards Points & 40 & 46 & 45 & 27 \\
\hline Excessive Annual Fees & 36 & 44 & 34 & 41 \\
\hline Failure to Use & 34 & 38 & 40 & 34 \\
\hline No Cash Out & 49 & 26 & 48 & 26 \\
\hline Too many Calls & 43 & 35 & 36 & 48 \\
\hline Received Threat Calls & 29 & 40 & 25 & 40 \\
\hline Received Legal Letters & 34 & 43 & 33 & 27 \\
\hline Embarrassing Situation & 37 & 26 & 31 & 25 \\
\hline Total Blogs & 469 & 450 & 460 & 414 \\
\hline
\end{tabular}

Table 4.2 shows the four banks $X, Y, Z$ and $W$ (whose identity is keep for confidentiality) distribution in terms of the negative online blogs posted. Bank $X$ have all the negative 
blogs except "no cash out" where 11 out of the 12 negative blogs is evident to the bank. Looking at the negative blogs themes, "no cash out" is not supported by the four major banks. Some notable themes which the researcher herself suffered are the negative blogs such as received threat calls, subpoena letter, and too many calls during customer service is evident from the theme extracted (Acosta, 2014).

Table 4.2: Banks $X, Y, Z$ and $W$ Complaints Based on Negative Blogs

\begin{tabular}{|c|c|c|c|c|}
\hline \multirow[b]{2}{*}{ Negative Blog } & \multicolumn{4}{|c|}{ Leading Banks } \\
\hline & $x$ & $Y$ & Z & W \\
\hline Failure to Transact Payments & $\sqrt{ }$ & $\sqrt{ }$ & $\checkmark$ & \\
\hline Failure to Reflect Payments & $\sqrt{ }$ & & $\sqrt{ }$ & $\checkmark$ \\
\hline Failure to Update & $\sqrt{ }$ & $\checkmark$ & $\sqrt{ }$ & $\checkmark$ \\
\hline Failure to Give Discounts & $\sqrt{ }$ & & & \\
\hline No rewards Points & $\sqrt{ }$ & $\sqrt{ }$ & $\checkmark$ & $\checkmark$ \\
\hline Excessive Annual Fees & $\sqrt{ }$ & $\checkmark$ & $\sqrt{ }$ & $\checkmark$ \\
\hline Failure to Use & $\sqrt{ }$ & $\sqrt{ }$ & $\sqrt{ }$ & $\checkmark$ \\
\hline \multicolumn{5}{|l|}{ NO Cash Out } \\
\hline Too many Calls & $\sqrt{ }$ & $\sqrt{ }$ & $\sqrt{ }$ & $\checkmark$ \\
\hline Received Threat Calls & $\sqrt{ }$ & $\checkmark$ & $\sqrt{ }$ & $\checkmark$ \\
\hline Received Legal Letters & $\sqrt{ }$ & & & \\
\hline Embarrassing Situation & $\checkmark$ & $\sqrt{ }$ & $\sqrt{ }$ & $\checkmark$ \\
\hline
\end{tabular}

2. Analyzing the negative blogs and be able to produce useful information for the visa and master cards holders.

\section{Blogs in Using Credit Cards}

In this section, the blogs of credit cards users were collated and collected to feed in the Semantria software for analysis. The Semantria reveals some of the attributes correlating the results and perceptions of credit card holders as presented in the succeeding tables.

For brevity of discussion, Table 4.3 is the chunk of the complete table referring to the blogs extracted from online blogging site in using credits cards. There are 30 blogs selected and fed to the Semantira software, however only 16 blogs were presented in this sections. Complete listing of the blogs is seen in Appendix B of the documents. The blogs were coded and transformed and edited to suit the blog analysis formats. 
Table 4.3: The Collected Blogs from Credit Cards Users.

\begin{tabular}{|c|c|}
\hline Document $\mathrm{v}$ & Source Text \\
\hline 1 & My visa master card limited my expenses. However, I am afraid in using all my credit cards. \\
\hline 2 & I will not pay my bills unles cleared by the billing department. I never been to Thailand to incur expenses. I \\
\hline 3 & I was scammed using my credit cards. I was deducted amounting to $\$ 60,000,00$. I am veryh disappointed. \\
\hline 4 & I heard that most of the old debts, they have no longer available since it has been charged off. If they cannot \\
\hline 5 & Someone use my credit cards while I am away in my office. It turns out that it was hacked. My credit card \\
\hline 6 & It sounds like this debt collector is using a scare tactic just to intimidate you. If you can't pay it, you can't pay it. \\
\hline 7 & I dont intend to used my credit as an emergency. An emergency fund is important, but it may never be \\
\hline 8 & I don't pay my credit card unless they will correct the reflected amount which I never enjoy it. \\
\hline 9 & I used to love collecting points, but now you can't even redeemed them. It almost pointless \\
\hline 10 & I cannot used when I redeemed points. \\
\hline 11 & I was not informed about the annual membership fee. Is there a way to be free. I lareacky purchased a lot with \\
\hline 12 & Yery bad. I was scammed in Thailand. \\
\hline 13 & My Master cards has no worthy in Russia. Everthing in Russia uses pin to pruchase. \\
\hline 14 & My Visa is not working in the Middle East. I have settled when I travelled but it was not updated immediately. \\
\hline 15 & I've been looking to witch checking accounts and have been on the look out for a better card than my visa \\
\hline 16 & I've had this card for 5 years and agree, it is great! I just used my points toget the following discounts for my \\
\hline
\end{tabular}

Table 4.4 is the comments and sentiment details of the blogs in using the credit cards. The table reveals that out of the twenty two (22) chunks of comments, twelve (12) is negative or $55.1 \%$, eight (8) or $35.36 \%$ for neutral and two (2) or $9.04 \%$ for positive. Thus the result tends to be on the negative side of sentiment. It can be notice also that blog item one were processed four times in four (4) different category such as Business, Computers, Finance and Games. The four categories belong to negative sentiment. Blog item 3 and 4 were processed into two category, both in Business and Finance. It can also be observed that blog item 5 were process four (4) times in the category of Business, Finance, Games, Mobiles application and other properties that can be derived from the table.

Table 4.4: Comments Category and Sentiment Details

\begin{tabular}{|c|c|c|c|c|c|}
\hline Document ID & Source Text & \begin{tabular}{r|} 
Wikipediam"' \\
Category \\
\\
\end{tabular} & $\begin{array}{l}\text { Wilkipedia"' } \\
\text { Category } \\
\text { Strength } \\
\end{array}$ & $\begin{array}{c}\text { Woikipedia } \\
\text { Category } \\
\text { Sentiment }\end{array}$ & $\begin{array}{l}\text { Wikipedia Category } \\
\text { Sentiment }+ \text { - }\end{array}$ \\
\hline 1 & My visa master card limited my expenses. However, I am afraid in & Business & 0.556423664 & -0.540000081 & negative \\
\hline 1 & My visa master card limited my expenses. However, I am afraid in & Computers & 0.480602086 & -0.540000021 & negative \\
\hline 1 & My visa master card limited my expenses. However, I am afraid in & Finance & 0.955595791 & -0.539999962 & negative \\
\hline 1 & My visa master card limited my expenses. However, I am afraid in & Games & 0.675629318 & -0.540000021 & negative \\
\hline 3 & I was scammed using my credit cards. I was deducted amounting to & Business & 0.470110118 & -0.48999998 & negative \\
\hline 3 & I was scammed using my credit cards. I was deducted amounting to & Finance & 1 & -0.49000001 & negative \\
\hline 4 & I heard that most of the old debts, they have no longer available & Business & 1 & -0.279073268 & neutral \\
\hline 4 & I heard that most of the old debts, they have no longer available & Finance & 0.704070449 & -0.307217509 & neutral \\
\hline 5 & Someone use my credit cards while l am away in my office. It turns & Business & 0.604172885 & 0 & neutral \\
\hline 5 & Someone use my credit cards while I am away in my office. It turns & Finance & 1 & 0 & neutral \\
\hline 5 & Someone use my credit cards while l am away in my office. It turns & Games & 0.569458425 & 0 & neutral \\
\hline 5 & Someone use my credit cards while l am away in my office. It turns & Mobile_phones & 0.509141624 & 0 & neutral \\
\hline 7 & I dont intend to used my credit as an emergency. An emergency fund & Business & 0.672332644 & -0.650000036 & negative \\
\hline 7 & I dont intend to used my credit as an emergency. An emergency fund & Finance & 0.888531148 & -0.649999976 & negative \\
\hline 8 & I don't pay my credit card unless they will correct the reflected & Business & 0.60072279 & -0.107800007 & neutral \\
\hline 8 & I don't pay my credit card unless they will correct the reflected & Finance & 0.713271916 & -0.107799999 & neutral \\
\hline 13 & My Master cards has no worthy in Russia. Everthing in Russia uses & Computers & 0.866055827 & -0.597800016 & negative \\
\hline 13 & My Master cards has no worthy in Russia. Everthing in Russia uses & Electronics & 0.676379859 & -0.597799957 & negative \\
\hline 13 & My Master cards has no worthy in Russia. Everthing in Russia uses & Finance & 0.583441556 & -0.597800076 & negative \\
\hline 15 & I've been looking to switch checking accounts and have been on the & Finance & 0.642931342 & 0.300000012 & neutral \\
\hline 16 & l've had this card for 5 years and agree, it is great! I just used my & Finance & 0.710842013 & 0.547483087 & positive \\
\hline 16 & 'Yve had this card for 5 years and agree, it is great! I just used my & Mobile_phones & 0.484786361 & 0.547483087 & positive \\
\hline
\end{tabular}




\section{Proposed Business Spend Analyzer Model}

In lieu of the negative online blogs of different card holders where they air their frustration and disappointment, it becomes evident that majority of bloggers have been problematic with the system of the credit card system primarily because of paying the debt where the credit become more frequent and outside within the allowable budget. Thus, it contributes to bad or delinquent account. For this matter, the proponent proposed a business model that lessens or the payment at the same time an spent analyzer is being introduced to floated credit cards. At the end of a specific time, the creditor will be able to manage payment and eventually move out to the net of debt.

\section{Business Model}

A typical Visa transaction begins when the cardholder presents Visa-branded card to a merchant for the payment of goods or services. The first step of the transaction is the authorization. It is the process of approving or declining a transaction before a purchase is finalized. The following diagram illustrates the steps involved in the authorization process:

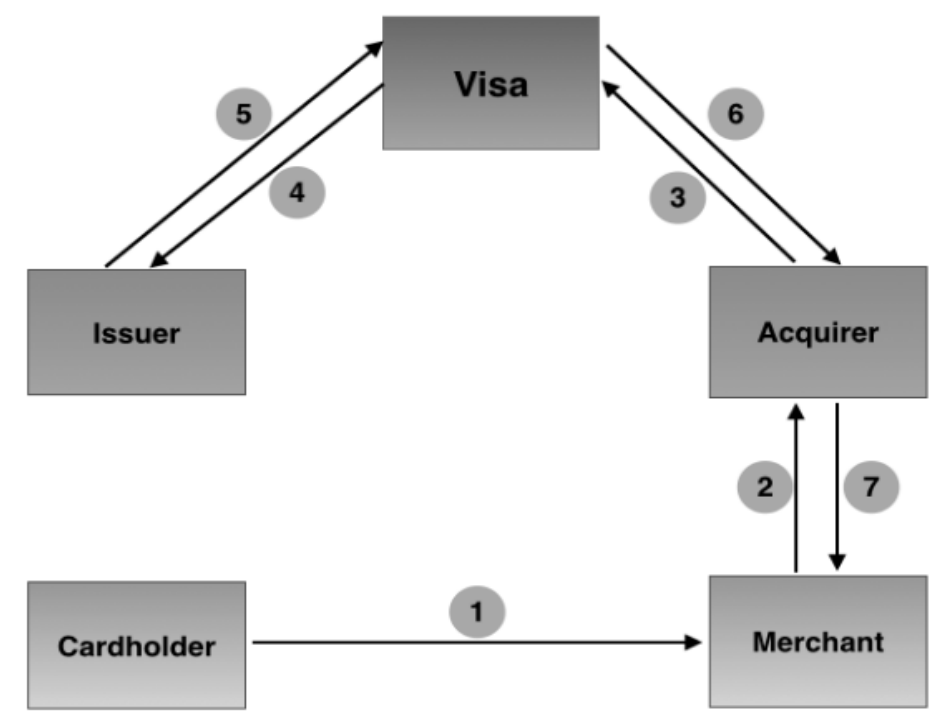

Figure 1: The Original Business Model (Visa Business Model, 2015)

1. The cardholder provides a Visa card to the merchant for the payment. The merchant point of sale (pos) terminal reads the account number and other data encoded on the card's magnetic stripe or electronic chip.

2. The merchant terminal transmits the card information and transaction amount to the acquirer or the acquirer processor.

3. The acquirer or acquirer processor combines the transaction information into an authorization request message and transmits it to Visa.

4. Visa identifies the appropriate card issuing bank and routes routes the authorization request to the issuer or the issuer processor for review.

5. The issuer or the issuer processor receives the request and then executes a series of inquiries into its account systems to: assess the potential risk of fraud for the transaction; establish that the account is in good standing; and verify that the cardholder has 
sufficient credit to cover the amount of the transaction. Then it approves or denies the transaction and returns an authorization response message to Visa.

6. Visa routes the authorization response to the acquirer or the acquirer processor.

7. The acquirer or the acquirer processor transmits the result of the authorization request to the merchant terminal.

If the transaction is approved, the merchant delivers the goods or services to the cardholder. Now, the money needs to be transferred to the merchant account with the acquirer. This is part of the clearing and settlement process.,

Implications of the Visa Model. Now, what do issuers, acquirers, and Visa gets out of this transaction. If the cardholder makes a $\$ 100$ payment, it is not completely transferred to the merchant account. The merchant gets the amount net of the merchant discount fee. If the merchant discount fee is $2.4 \%$, then the merchant would receive $\$ 97.60$ from the transaction. The rest of $\$ 2.40$ is split unevenly between the issuer and the acquirer, depending upon the interchange rate. In case of an interchange rate of $1.8 \%$, the issuer will keep $\$ 1.80$ and the acquirer will keep $\$ 0.60$. Issuer gets to keep more of the merchant discount fee because of a higher risk of payment default from the cardholder. Visa does not make money from the individual transactions. Instead, it earns revenues from the issuers and acquirers based upon the overall payment volumes and number of transactions processed.

However, given the revised model as shown in Figure 2, the Acquirer can be removed to save money from the credit card holder.

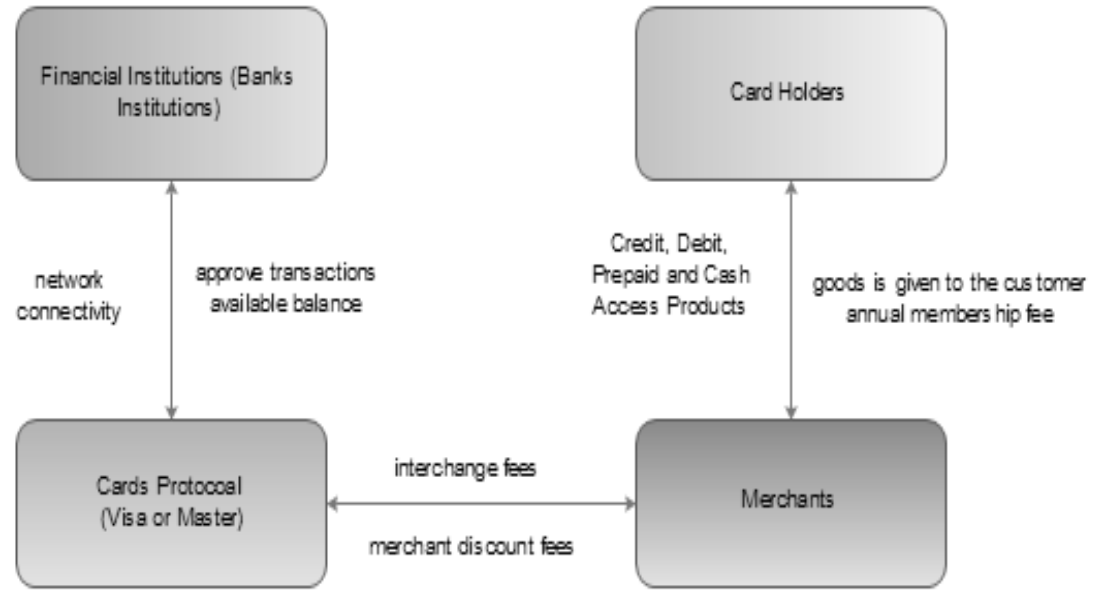

\section{Spent Analyzer}

Figure 2: The Modified Business Model

The traditional methods of repaying credit card debt include making a payment over the counter or internet towards your bill, but when you're simply covering the interest, the debt isn't reducing but debt is ballooning. Figure 3.1.a shows the typical way of budgeting where you enter your income, budget the income and spend the budget, however, the money at hand is not enough. A perennial problem in using a credit cards is 
"spend a lot and pay later", unknowingly, your budget were drained by interest. So how can we recover?

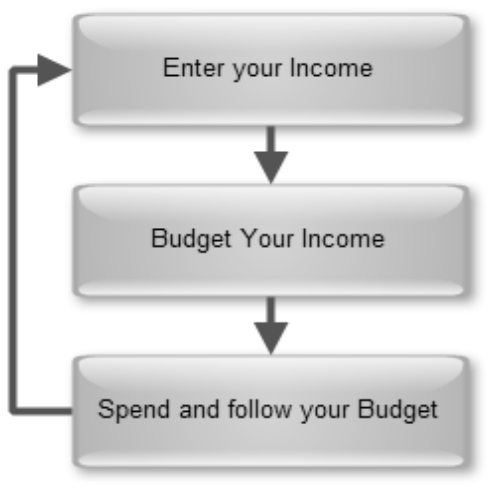

Figure 4.3.a - Normal Steps in Budgeting

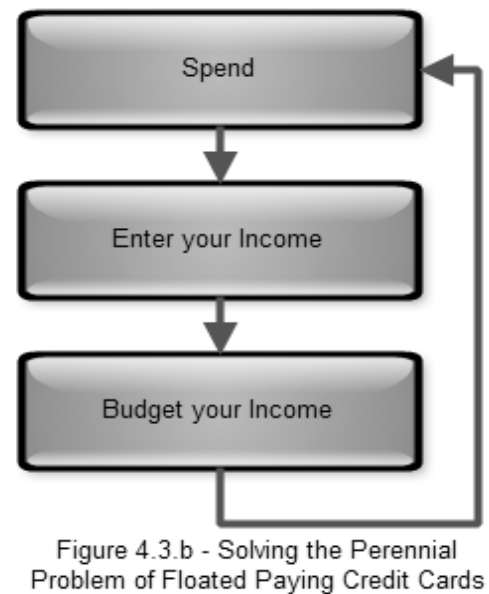

Defying the traditional payment scheme, Figure 3 shows a mechanism that allows the credit cards holders to slowly recover his debt into a better budgeting scheme, applying the concepts "Spend, Enter your income and budget your income scenario. The Spend process refers to the time that a credit cards holder can no longer pay the total amount of his/her bills but spend too much using the credit cards. Enter you income process based on the figures, compare the income to the current credit and perform necessary adjustment. Budget your income process allows you to slowly paying the bills by gradually adjusting the payment scheme based on the small available funds. The process will continue until a normalized debt control or if not zero credit is achieved. The following situation/schenarion provides the necessary illustrative computation to perform wise spending based on the small amount available also known as "spent analyzer".

When a card holder used his/her credit cards, you're given a grace period to pay things off. Normally, as long as you pay it in full within that time frame, then you are not charged interest. Many people take advantage of this. They charge this month, then pay it off next month. Because you pay it off every month, you feel like you're doing fine. But in reality, you're a month behind. It's often difficult to realize this because it's hard to visualize. For the purpose of illustration the author used Microsoft Excel and small amount of money to illustrate the modified Figure 4.3.a. into Figure 4.3.b process.

\section{Sample Situation:}

January: The credit card holder charges a bunch of spending on his/her credit card. Pay bills with this card, buy groceries, etc. Everything goes on the card. The total is 9,000 pesos.

February: The credit card holder avoids interest and then paid the full amount. The salary is 10,000 . He/she paid in full. Great, now you can pay the bill.

Here's the problem: There's only 1,000 left available budget. You can't budget for the entire month now because the vast majority of your money went to the credit card. So 
what do you do? You charge everything in the credit cards and the cycle starts all over again.

Here it is in a nutshell: You are using this month's money to cover last month's spending. Since that money is gone, you can't budget for this month's spending. Instead of:

Enter Income > Budget Income > Spend according to that plan as seen in Figure 4.3.a., Your steps are:

Spend > Enter Income > Budget to cover past spending based on Figure 4.3.b.

2. Breaking the Cycle.

There are many options but then a more realistic and more doable is to treat the balance as debt and pay it off slowly. In this method the credit card holder can be able to budget proactively for future spending and see the debt in one place.

In this case budget the 4,000 where you need it first. Whatever is left is budgeted toward the credit card category and that's what you send toward the old balance. In February, you were able to budget 900 toward the debt after taking care of other areas.

For the purpose of brevity and discussion, all the tables in succeeding sections were modified and re-structured. As shown in Table 4.9.a, the salary of the card holder is initially at P4000 pesos with outflows of P-6270. Based on the initial salary, a 4000 is not enough to pay all the expenses with a negative balance of P2270.

Table 4.5 a Spent Analyzer - Analyzing the Budget and Outflows - Level 0

\begin{tabular}{|c|c|c|c|}
\hline \multicolumn{4}{|c|}{ Spent Analyzer } \\
\hline \multirow{2}{*}{ Categories } & Budgeted & Outflows (-) & Balance \\
\hline & 4000 & 6270 & -2270 \\
\hline Credit Card & 900 & 3700 & -2800 \\
\hline Visa & 900 & 3700 & -2800 \\
\hline Monthly Balls & 1800 & 1800 & $\mathbf{0}$ \\
\hline Rent & 1000 & 1000 & 0 \\
\hline Phone & 200 & 200 & 0 \\
\hline internet & 200 & 200 & 0 \\
\hline Water & 100 & 100 & 0 \\
\hline Electricity & 100 & 100 & 0 \\
\hline Car Payment & 200 & 200 & 0 \\
\hline Eveyday Expenses & 900 & 770 & 130 \\
\hline Groceries & 400 & 375 & 25 \\
\hline Fuel & 200 & 180 & 20 \\
\hline Spending Money & 100 & 80 & 20 \\
\hline Households Goods & 100 & 65 & 35 \\
\hline Entertainment & 100 & 70 & 30 \\
\hline Misclenaneous Funds & 400 & 0 & 400 \\
\hline Emergency Fund & 100 & & 100 \\
\hline Car Repairs & 100 & & 100 \\
\hline CarInsurance & 100 & & 100 \\
\hline Others & 100 & & 100 \\
\hline
\end{tabular}


Transforming Online Negative Blogs in the Use of Credit Cards .....

Table 4.5.b Spent Analyzer - Restructuring the Payment Scheme of Credit Card - Level 1

\begin{tabular}{|c|c|c|c|}
\hline \multicolumn{4}{|c|}{ Spent Analyzer } \\
\hline \multirow{2}{*}{ Categories } & Budgeted & Outflows (-) & Balance \\
\hline & 4000 & 2325 & 1675 \\
\hline Credit Card & 1250 & 0 & 1550 \\
\hline Visa & 1250 & & 1550 \\
\hline Monthly Bills & 1800 & 1600 & 200 \\
\hline Rent & 1000 & 1000 & 0 \\
\hline Phone & 200 & 200 & 0 \\
\hline internet & 200 & 0 & 200 \\
\hline Water & 100 & 100 & 0 \\
\hline Electricity & 100 & 100 & 0 \\
\hline Car Payment & 200 & 200 & 0 \\
\hline Eueyday Expenses & 750 & 725 & 155 \\
\hline Groceries & 400 & 350 & 75 \\
\hline Fuel & 200 & 170 & 50 \\
\hline Spending Money & 50 & 60 & 10 \\
\hline Households Goods & 50 & 70 & 15 \\
\hline Entertainment & 50 & 75 & 5 \\
\hline Misclenaneous Funds & 200 & 0 & 600 \\
\hline Emergency Fund & 50 & & 150 \\
\hline Car Repairs & 50 & & 150 \\
\hline CarInsurance & 50 & & 150 \\
\hline Others & 50 & & 150 \\
\hline
\end{tabular}

The total debt in using the credit card is P3700. Initially the creditor (credit card holder) cannot pay the whole amount, given a salary of P4000; it will leave the creditor of P300.

The P300 cannot suffice the expenses for the next month.

Table 4.5.c - Spent Analyzer - Restructuring Payment with Zero Incurred Expenses of Credit Card Level 2

\begin{tabular}{|c|c|c|c|}
\hline \multicolumn{4}{|c|}{ Spent Analyzer } \\
\hline \multirow{2}{*}{ Categories } & Budgeted & Outflows (-) & Balance \\
\hline & 4000 & 2450 & 955 \\
\hline Credit Card & 1550 & 0 & $\mathbf{0}$ \\
\hline Visa & 1550 & & $\mathbf{0}$ \\
\hline Monthly Bills & 1800 & 1800 & 200 \\
\hline Rent & 1000 & 1000 & 0 \\
\hline Phone & 200 & 200 & 0 \\
\hline internet & 200 & 200 & 200 \\
\hline Water & 100 & 100 & 0 \\
\hline Electricity & 100 & 100 & 0 \\
\hline Car Payment & 200 & 200 & 0 \\
\hline Eveyday Expenses & 650 & 650 & 155 \\
\hline Groceries & 375 & 420 & 30 \\
\hline Fuel & 175 & 150 & 75 \\
\hline Spending Money & 25 & 20 & 15 \\
\hline Households Goods & 25 & 20 & 20 \\
\hline Entertainment & 50 & 40 & 15 \\
\hline Misclenaneous Funds & $\mathbf{0}$ & 0 & 600 \\
\hline Emergency Fund & & & 150 \\
\hline Car Repairs & & & 150 \\
\hline Car Insurance & & & 150 \\
\hline others & & & 150 \\
\hline
\end{tabular}


Table 4.5.d - Spent Analyzer - Normalizing the Credit Card Level 3

\begin{tabular}{|c|c|c|c|}
\hline \multicolumn{4}{|c|}{ Spent Analyzer } \\
\hline \multirow{2}{*}{ Categories } & \multicolumn{2}{|c|}{ Budgeted butflows (- } & \multirow{2}{*}{$\begin{array}{c}\text { Balance } \\
955 \\
\end{array}$} \\
\hline & 4000 & 6150 & \\
\hline Credit Card & 3700 & 3700 & $\mathbf{0}$ \\
\hline Visa & 3700 & 3700 & $\mathbf{0}$ \\
\hline Monthly Bills & 1800 & 1800 & 200 \\
\hline Rent & 1000 & 1000 & 0 \\
\hline Phone & 200 & 200 & 0 \\
\hline internet & 200 & 200 & 200 \\
\hline Water & 100 & 100 & 0 \\
\hline Electricity & 100 & 100 & 0 \\
\hline CarPayment & 200 & 200 & 0 \\
\hline Eveyday Expenses & 650 & 650 & 155 \\
\hline Groceries & 375 & 420 & -15 \\
\hline Fuel & 175 & 150 & 100 \\
\hline Spending Money & 25 & 20 & 20 \\
\hline Households Goods & 25 & 20 & 25 \\
\hline Entertainment & 50 & 40 & 25 \\
\hline Misclenaneous Funds & $\mathbf{0}$ & 0 & 600 \\
\hline Emergency Fund & & & 150 \\
\hline Car Repairs & & & 150 \\
\hline CarInsurance & & & 150 \\
\hline Others & & & 150 \\
\hline
\end{tabular}

The creditor paid an initial amount of P900 for the month of February while limiting the payment of other category as seen in Table 4.9.a. For Table 4.9.b, the creditor paid an amount of P1250 without further using the credit card while continuously adjusting the payment to other category. Thus, the balance debt of the credit becomes P1550 for the month of March. Based on the savings from Table 4.9.c - the spent analyzer for the month of April paid the amount of P1550; leaving the balance to zero (0) for the credit cards. In Table 4.9.d, normalizes the payment scheme for credit cards while savings in the other categories. The creditor now become free and ready to spend his/her earning wisely. After the correction, there's 3700 available to budget. The credit card holder decides to buckle down and just live on this money. The spent analyzer will continuously perform to the nth level till the value of the debt becomes manageable, if not zero (0) after several months of paying. This means you've used your credit card wisely and can pay the bill at any time. While both these walkthroughs were simplified, the concepts apply across the board. Either approach will get you there. Some people find it easier to just focus on the overspending in one place. Whichever approach you use, your goal should be to eliminate more and more of the red (negative) each month until it's gone. 


\section{Discussion}

Based on the results, there are 12 themes that dominantly observed from the 1793 blogs collected during the online collation of negative blogs. Out of the 1793 blogs, 929 is noted for Visa Card or 51.2 percent while the remaining 883 or 48.8 percent is allocated for Master Card.. The total male for visa cars is 469 while for master card is 460 , an almost equal number of bloggers for both credit cards. The female of visa is composed of 450 while 414 for master cards. It can be said that majority of the credit cards holder based on the gathered blogs are male. This statistics is valid because majority of the workforce are male almost $57 \%$ while woman is almost $47 \%$ (Houston Chronicle, 2013).

Four banks $X, Y, Z$ and $W$ (whose identity is kept for confidentiality) distribution in terms of the negative online blogs was posted. Bank $X$ have all the negative blogs except "no cash out" where 11 out of the 12 negative blogs is evident to the bank. Looking at the negative blogs themes, "no cash out" is not supported by the four major banks. Some notable themes which the researcher herself suffered are the negative blogs such as received threat calls, subpoena letter, and too many calls during customer service is evident from the theme extracted (Acosta, 2014).

Semantria software revealed that the digital transcripts is neutral with a score of -0.020 . Several negative and positive words have emerged in the transcripts making the analysis become a neutral as it was almost reaches 0.0 the falls within neutral values. Several negative words revealed the following words: annoying, disappointed, scare, never be, aggressive, hacked, and afraid whereas positive words are: worthy, updated, agree, recommended, feasible, love and sweet. The result as neutral does not mean negative but opportunities to consider by the customers in using the credit cards. Thus the results also coincides with the findings in the perceptions that it cannot be determined whether this is significant or not. For example the $z$ test results in Table 4.2 and $z$ test in Table 4.4 varies accordingly. There is a need to justify whether the neutral is being negative or more on the positive side. The succeeding Table 4.7 reveals the answer.

Comments and sentiment details of the blogs in using the credit cards reveals that out of the twenty two (22) chunks of comments, twelve (12) is negative or $55.1 \%$, eight (8) or $35.36 \%$ for neutral and two (2) or $9.04 \%$ for positive. Thus the result tends to be on the negative side of sentiment. It can be notice also that blog item one were processed four times in four (4) different category such as Business, Computers, Finance and Games. The four categories belong to negative sentiment. Blog item 3 and 4 were processed into two category, both in Business and Finance. It can also be observed that blog item 5 were process four (4) times in the category of Business, Finance, Games, Mobiles application and other properties that can be derived from the table.

In lieu of the negative online blogs of different card holders where they air their frustration and disappointment, it becomes evident that majority of bloggers have been problematic with the system of the credit card system primarily because of paying the debt where the credit become more frequent and outside within the allowable budget. Thus it contributes to bad or delinquent account. For this matter, the proponents proposed a business model that lessen or the payment at the same time an spent 
analyzer is being introduced to floated credit cards. At the end of a specific time, the creditor will be able to manage payment and eventually move out to the net of debt.

The study is an exploratory under the qualitative analysis and therefore the conclusion is valid based on the given data and based on the limited parameters. There are 1793 blogs considered and used in the study and 12 themes have emerged namely; failure to transact payments, failure to reflect payments, failure to update, failure to give discounts, no reward points, excessive annual fees, failure to use, no cash out, too many calls, received threats, legal letters and experienced embarrassing situation. Based on the analysis of the online negative blogs, Semantia software has been used and reveals that the sentiment analysis is .024 and generally neutral, however its neutrality tends to be more into negative as the number of negative blogs is becoming more evident against the positive words. Modifying the model and removing the Acquirer entity can save the credit card holders in paying the hidden cost and can just be converted to savings. The used of spent analyzer is acceptable as its gradually allow the credit card holder to recover from the net of debt.

Future research could be conducted, perhaps using an experimental approach where: consider thousands of suggestions, comments, remarks and negative blogs into a more sophisticated blogs analysis with the use of natural language processing thereby helping individual to understand their sentiments; instead of Semantria, a software should be develop to analyze intelligently the negative blogs and be able to establish the correlation to perceptions to understand better the disappointments of the credit card holders; the spent analyzer is not sufficient and it is only for recommendatory used and it is up to the individual to used it or not. For this, an educational avenue from the card issuer must be ensure to educate the credit card holder to be responsible and understand how credit cards interest ruin their credit portfolio; there should be an experimental design that invites consumers to use credit cards in a few situations and subsequently manipulate specific sets of interventions (e.g. interest rates, awareness messages [rational/affective]) to encourage responsible usage of credit cards ; ultimately, the decision to use credit cards responsibly falls on the hands of young consumers themselves. As such, young consumers are recommended to think carefully before they swipe their cards, have budgets, and if possible, apply for debit cards instead of credit cards to avoid situations of overspending.

"A change is hard to achieve but a difference is easy to accomplish. It only takes one person to make a difference. Start with you; make a difference then it will become a change!"

\section{References}

Anderson, L. M., \& Bateman, T. S. (2011). Cynicism in the workplace: Some Causes and Effects. Journal of Organizational Behavior, 18(5),449-

Anderson, M.L. (2011).Embodied cognition: a field guide. Artificial Intelligence: Field Review, 149, 91-130. 
Bank of America. (2016). The Advantage of Credit Cards. Equal Housing Lender. https://www.bankofamerica.com/credit-cards/education/advantages-of-credit-cards.go.

Bausch, P., Haughey M., \& Hourihan M. (2002). We Blog: Publishing Online with Weblogs. Wiley.

Bechara, A., \& Damasio, A. (2015). The Somatic Marker Hypothesis: a Neural Theory of Economic Decision-making. Games and Economic Behavior, 52, 336-372. Belk, R. W. (1988). Possessions and extended self. Journal of Consumer Research, 15, 139- 168.

Belk, R. W., \& Wallendorf, M. (2000).The scared meanings of money. Journal of Economic Psychology, 11, 35-67.

Bell, D. (1976). The Cultural Contradictions of Capitalis. New York: Basic Books.

Blodgett J., Granbois D.H., Walters R.G. (1993). The effects of perceived justice on complainants negative word-or-mouth behavior and repatronage intentions. Journal Retailing. Vol. 69(4). 399-428.

Burgoyne, C. B. \& Routh, D. A. (2011). Constraints on the Use of Money as a Gift at Christmas: The Role of Status and Intimacy. Journal of Economic Psychology.12, 47- 69.

Burns, S.N. \& Grove, S.K. (1993). The Practice of Nursing Research. Goodwood: National Book Printers

CA. Citizen Advice (2016). Problem with Credit Cards. Retrieved November 10, 2016 from https://www.citizensadvice.org.uk/debt-and-money/borrowing-money/creditcards/problems-with-credit-cards/.

Caldwell, M. (2009). Is it worth having a credit card to earn the rewards? About.com Guide. Retrieved from http://moneyfor20s.about.com/od/creditcards/f/creditcardrewards.htm

CCB. Credit Cards Blog. (2016). Retrieved November 29, 2016 from https://www.google.com.ph/webhp?sourceid=chrome-instant\&ion=1\&espv=2\&ie=UTF8\#q=blogs\%20for\%20credit\%20cards

Cortina, J.M. (1993). What is coefficient alpha? An of theory and applications" Journal of Applied Psychology. pp. 98-104. http://psychweb.psy.umt.edu/denis/datadecision/front/cortina_alpha.pdf

Feinberg, R.A. (1986). Credit cards as spending facilitating stimuli: a conditioning interpretation. Journal of Consumer Research, 13(3), 348-356. http://dx.doi.org/10.1086/209074

Fiske, J. (2011). Introduction to Communication Studies. London: Routledge

Fiske, S. T., \& Taylor, S. E. (2011). Social cognition (2nd ed.). New York: McGraw-Hill. 
George, D., \& Mallery, P. (2003). SPSS for Windows step by step: A simple guide and reference. 11.0 update (4th ed.). Boston: Allyn \& Bacon.

Glimcher, Camerer, Poldrack \& Fehr (2011) Neuroeconomics: Decision Making and the Brain. Glimcher Paul W., Camerer Colin, Poldrack Russell, Fehr Ernst (Eds.) Academic Press: London, 2008. ISBN 9780123741769.

Hirschman, E.C. (1979). Differences in consumer purchase behavior by credit card payment system. Journal of Consumer Research, 6 (1), 58-66. http://dx.doi.org/10.1086/208748

Joy, Athena. (2015). A Study on Customer's Perception Towards Credit Cards. School of Management Studies. 2249-55X. Vol. 5(6).

Jusoh, Zuroni \& Lim, Lim Yen. (2012). Personal Knowledge and Card Practices Among Working Adults in Malaysia. International Journal in Social Science, 3(7), 176-185.

Key, James P. (2007). Research Design in Organizational Education. U.S.A.: Oklahoma, Oklahoma University Publishing House.

Lakoff, G., \& Johnson, M. (2011). Philosophy In The Flesh: the Embodied Mind and its Challenge to Western Thought. Basic Books. ISBN 0465056741.

Livingstone, S.M. and Lunt, P.K. (1992). Predicting personal debt and debt repayment: psychological, social and economic determinants. Journal of Economic Psychology, 13, 111-134. http://dx.doi.org/10.1016/0167-4870(92)90055-C

Mandell (1990). The Credit Card Industry: A History. Boston: Twayne Publishing House. McLuhan, Marshall. 1964. Understanding Media: The Extensions of Man. New York: McGraw-Hill.

Mouton, Johann (2011). Understanding Social Research. South Africa: Cape Town Oxford University Press Southern Africa, 2001

O’Keeffe, P.J.L., Desai, A.J., Foroughi, K., Hibbett, G.J., Maxwell, A.F., Sharp, A.C., Taverner, N.H., Ward, M.B. and Willis, F.J.P. (2005). Current developments in embedded value reporting. British Actuarial Journal, 11 (3), 407-479. http://dx.doi.org/10.1017/S1357321700003226

Oullier and Basso (2010). Embodied Economics: How Bodily Information Shapes the Social Coordination Dynamics of Decision-making (http://www.ncbi.nlm.nih.gov/pubmed/20026467) accessed date 18th June 2011.

Parrish, L. (2009). Time Line of Credit Cards. N.p.: Credit Card Flyers.com. 
Polit, D.F. \& Hungler, B.P. (2013). Research Methodology. USA: New York Harcourt Brace College Publishing House

Ragihurbir \& Srivastava (2010) "The Denomination Effect," Journal of Consumer Research, 36 (4), 701-13.

Reimann \& Bechara (2012) The Somatic Marker Framework as a Neurological Theory of Decision-making: Review, Conceptual Comparisons, \& Future Neuro-economics Research, Journal of Economic Psychology (2010) Volume: 31, Issue: 5.

Rendahl, S. (2015). Frame analysis: From interpersonal to Mass Communication. Paper Presented to Central State Communication Association, Indianapolis, Indiana. 164

Roberts, J.A. (1996). Green consumers in the 1990s: profile and implications for advertising. Journal of Business Research, 36 (3), 217-231. http://dx.doi.org/10.1016/0148-2963(95)00150-6

RPS. Retailer Payment Systems: Relative Merits of Cash and Payment Cards, Economists Inc., (Nov. 19, 2014).

See-San Juan, M., (2015). Sociological Inquiry into Credit Card Delinquency in the Philippines.

Semantria (2014). Retrieved July 29, 2014 from https://semantria.com/features/themes

Siddiqui, K., Ahmed, Anjum, M. (2013). Perceptions Towards Credit Card Usage: Factor Analytic Finding from Pakistan (September 1, 2013). International Journal of Economics Business and Management Studies. Vol. 2, No. 3. 128-135.

Soman, D. (2001). Effects of Payment Mechanism on Spending Behavior: The role of Rehearsal Immediacy of Payments. Journal of Consumer Research, 27, 460-471.

Soman, D. (2013). The Effect of Payment Transparency on Consumption: Quasi Experiments from the Field. Marketing Letters, 14 (3), 173-183.

Soman, D. and Cheema, A. (2002). The effect of credit on spending decisions: the role of the credit limit and credibility. Marketing Science, 21 (1), 32-53. http://dx.doi.org/10.1287/mksc.21.1.32.155

Soman, D. and Cheema, A. (2002). The effect of credit on spending decisions: the role of the credit limit and credibility. Marketing Science, 21 (1), 32-53. http://dx.doi.org/10.1287/mksc.21.1.32.155

Soman, D. and Cheema, A. (2002). The effect of credit on spending decisions: the role of the credit limit and credibility. Marketing Science, 21 (1), 32-53.

Spector, P. E. (1992). Summated Rating Scale Construction: An introduction, Newbury Park: Sage Publications. 
Steele, Jason (2015). Credit.com What's the Difference Between Visa and Master Card? EVERYDAY MONEY CREDIT CARDS.

Straub, D. W. (1989) "Validating Instruments in MIS Research," MIS Quarterly (13) 2, pp. 147-169

Streiner D. (2003). Starting at the beginning: an introduction to coefficient alpha and internal consistency. Journal of personality assessment. 80:99-103.

Sudhagar, S. (2012). A study on perception and awareness on credit cards among bank customers in India. IOSR Journal of Business and Management. 2278-487X V. 2(3). 14-23.

Tavakol M., \& Dennick R. (2011). Making sense of Cronbach's alpha. International Journal of Medical Education. 2011; 2:53-55 Retrieved June 12, 2014 from http://www.ijme.net/archive/2/cronbachs-alpha.pdf

Thaler R. H. (2012). Toward a Positive Theory of Consumer Choice, in P. E. Earl: Behavioral Economics.

Thaler, R. H. (2012). Mental Accounting \& Consumer Choice. Marketing Science, 4, 199214.

Tversky, A. \& Kahneman, D. (2011) Judgment under Uncertainty: Heuristics \& Biases Science, New Series, 185 (4157), 1124-1131

Wiggins, O. (2008). Calling on gospel to call off debt. Washington: Washington Post.

$x x x x x x x x-----x x x x x x x x$ 